\title{
ДОСЛІДЖЕННЯ СУЧАСНОГО СТАНУ ТА ПЕРСПЕКТИВ РОЗВИТКУ СПОРТИВНОГО ТУРИЗМУ В УКРАЇНІ
}

\section{RESEARCH OF THE CURRENT STATE AND PROSPECTS FOR THE SPORTS TOURISM DEVELOPMENT IN UKRAINE}

\author{
Писарева Ірина Володимирівна \\ кандидат економічних наук, \\ Харківський національний університет міського господарства імені О.М. Бекетова \\ ORCID: https://orcid.org/0000-0003-1433-9104 \\ Григоренко Аліна Юріївна \\ магістерка, \\ Харківський національний університет міського господарства імені О.М. Бекетова \\ ORCID: https://orcid.org/0000-0002-9664-2758
}

Pysareva Iryna, Hryhorenko Alina

O.M. Beketov National University of Urban Economy

\begin{abstract}
В статті охарактеризовано поняття спортивного туризму; виявлена роль даного виду, його головні фрункції; наведені особливості, які відрізняють спортивно-оздоровчий туризм від інших видів туризму; зазначено як він впливає на стан економічно та соціального розвитку країни; вказані різновиди спортивного туризму; наведено найпопулярніші регіони розвитку спортивного туризму в Україні; визначено організаційні центри, які займаються цим видом туризму; проаналізовано стан спортивно-оздоровчого туризму; зазначені проблеми, а також запропоновані можливі шляхи їх рішення; виявлені пріоритетні напрямки спортивного туризму та перспективи його розвитку; зроблені висновки щодо створення позитивних умов для розвитку спортивного туризму в Україні; запропоновано пропозиції щодо тих регіонів, де спортивний туризм популярний та регіонів, де він розвинений гірше, або взагалі відсутній.
\end{abstract}

Ключові слова: туризм, спортивний туризм, спортивно-оздоровчий туризм, спортивні заходи.

В статье охарактеризованы понятия спортивного туризма; обнаружена роль данного вида, его главные фрункции; приведены особенности, отличающие спортивно-оздоровительный туризм от других видов туризма; указано как оно влияет на состояние экономического и социального развития страны; указаны разновидности спортивного туризма; приведены самые популярные регионы развития спортивного туризма в Украине; определены организационные центры, занимающиеся этим видом туризма; проанализировано состояние спортивно-оздоровительного туризма; указанные проблемы, а также предложены возможные пути их решения; выявлены приоритетные направления спортивного туризма и перспективы его развития; сделаны выводы о создании положительных условий для развития спортивного туризма в Украине; предложены предложения по тем регионам, где спортивный туризм популярен и регионов, где он развит хуже или вообще отсутствует.

Ключевые слова: туризм, спортивный туризм, спортивно-оздоровительный туризм, спортивне мероприятия.

The article describes the concept of sports tourism. It is determined that sports tourism is an extreme and active kind of travel, which involves overcoming a route for a long distance on the complexity of obstacles in the natural environment. The role of this species is revealed, its main functions to which wellness, rehabilitation, psychotherapeutic, aesthetic and cognitive. The features that distinguish sports and recreation tourism from other types of tourism are given. Stated as it affects the state of economic and social development of the country. The varieties of sports tourism are considered, which include a pedestrian, mountain, ski, water, speleotourism, sailing, automobile, cycling, motorcycle, combined tourism. The most popular regions of sports tourism development in Ukraine are given. It is determined that the Carpathian region is the most developed region of sports and recreation tourism. Organizational centers that deal with this type of tourism are identified, namely sections, tourist unions and clubs. These problems, as well as possible ways of their decision. The difficulties with which sport and recreation tourism in their development also encountered, are the economic problems of society in the first place. To date, almost there is no support for this type of state and community. Also decreases in mass to a higher level competition. The main problem is superfluous bureaucratic procedures, without which athletes can not be admitted to the competition. Conclusions 
made to create positive conditions for the development of sports tourism in Ukraine. Sports tourism can completely calmly develop in the conditions of the economic crisis. After all, it is not the main large material costs, it is capable of existing in the environment. Proposals for those regions where sports tourism are popular and regions where it is worse, or at all. Improving the development of sports tourism is possible by improving the infrastructure, promoting this type of tourism among children and young people, create new pedestrian, water and bicycle routes, to increase the skills of sports tourism.

Keywords: tourism, sports tourism, sports and health tourism, sports events.

Постановка проблеми. Спортивний туризм займає важливу частину життя більшості людей у світі та добре впливає на здоров'я та загальний стан організму. Сьогодні це дуже поширений феномен.

Спортивний туризм складається з різноманітних оздоровчих, пізнавальних, спортивних, економічних і других функцій. Головними проблемами, 3 якими зустрівся цей вид туризму в своєму розвитку це економічні та соціальні проблеми розвитку суспільства. Також ця проблема пов'язана з тим, що зараз майже немає підтримки спортивного туризму від самого суспільства та держави.

Актуальність роботи полягає в тому, що спортивний туризм займає важливу частину життя більшості людей у світі та добре впливає на здоров'я та загальний стан організму.

Із розвиток суспільства та підвищення рівня життя людей, спортивний туризм в Україні поступово стає однією із найбільш швидкозростаючих галузей і $є$ національним видом спорту, який має багатовікові традиції.

Спортивний туризм не вимагає великих матеріальних витрат, таким чином $€$ соціальним видом спорту. Ним займаються як молодь, школярі, студенти, вчителі, лікарі, хто не має великих доходів, так і бізнесмени, інтелігенція та інші, у кого є більше можливостей .

Постановка завдання. Метою дослідження $\epsilon$ аналіз сучасного стану та перспектив розвитку спортивного туризму в Україні.

Аналіз останніх досліджень і публікацій. Дослідженнями розвитку спортивного туризму займались багато вітчизняних та закордонних вчених, таких, як М.П. Мальська, В.В. Худо і В.І. Цибух [1], В.В. Абрамов [2], П. де Кнопа та Дж. Стендевен [3], Джеймс Е.С. Хігхем [4], Х.Дж. Гібсон [5] та інші. За результатами аналізу визначень поняття «спортивний туризм» ми пропонуємо визначати його як екстремальний і активний вид подорожей, який передбачає подолання маршруту на великій відстані за складністю перешкод в природному середовищі. Він вимагає від туристів гарної фрізичної підготовки та технічних навиків.

Виклад основного матеріалу дослідження. Спортивний туризм знаходиться на перехресті системи фрізичної культури і спорту та туристичної індустрії. Він виконує різноманітні фрункції: оздоровчі, пізнавальні, рекреаційні, виховні, спортивні, економічні та інші. Якщо говорити про перспективи розвитку спортивно-оздоровчого туризму, то слід звернути увагу на його соціальний характер. Тому що, на відміну від інших форм відпочинку, він доступний для більшої частини населення. Тому головним завданням $€$ злиття спортивного туризму в соціальний механізм літнього дитячого оздоровлення.

Спортивний туризм залучає населення вести здоровий спосіб життя, розвивати інтелект та підтримувати фрізичну фрорму завдяки залучення до участі в спортивних змаганнях та походах різної складності . Він $є$ невід'ємною частиною спорту та фрізичної культури. Також він впливає на підвищення трудової активності, особистих потреб, відпочинку та розвитку взаємного міжнародного спілкування

До основних видів спортивного туризму, які визначаються способом пересування, відносять такі: пішохідний, гірський, лижний, водний, спелеотуризм, вітрильний, автомобільний, велосипедний, мотоциклетний, комбінований туризм [8].

Історія спортивного туризму свідчить, що масовим цей рух стає лише за умов стабільності економічної ситуації та створенні достатніх матеріальних умов життя та зростанні реальних доходів населення. Відсутність державного фрінансування призвела до того, що структури управління оздоровчо-спортивним туризмом, які існували раніше, в основному припинили свою діяльність.

Розвиток спортивного туризму (СТ) в Україні переживає суттєвої зміни. Зокрема, перестають бути актуальними такі риси спортивного туризму, як його соціальний і масовий характер, державна фрінансова підтримка, в тому числі і дитячо-юнацького туризму, система підготовки спортивних та громадських туристських кадрів. Такі зміни зумовлені низкою чинників, як об'єктивного, так і суб'єктивного характеру.

Більшість структур управління спортивним туризмом перестали існувати через те, 
що в країні відсутня державна фрінансова підтримка. Таким чином Міжнародний туристсько-спортивний союз (МТСС) взяв на себе відповідальність організовувати діяльність спортивного туризму. З'явився він в 1990 році та членами союзу є СНД і Балтії, разом з цим і Україна.

Україну, як дійсного члена МТСС та МФСТ, представляє як Туристсько-спортивний союз (ТССУ) і Федерація спортивного туризму (ФСТУ). Ці громадські організації працюють на основі затверджених статутів та мають на меті об'єднання зусиль членів Союзу та Федерації та координацію їхньої діяльності щодо сприяння розвитку спортивно-оздоровчого туризму в Україною [2, с. 367]. Центрами, що організовують розвиток спортивного туризму в країні є секції, туристські союзи та клуби.

В таблиці 1 зазначена Характеристикаспортивних туристських походів в 2018-2020 роки за даними ЦМКК спортивного туризму

Для порівняння показані актуальні на сьогоднішній день показники дані Центральної маршрутно-кваліфрікаційної комісії (основна

Характеристика спортивних туристських походів в 2018-2020 роки за даними ЦМКК спортивного туризму

\begin{tabular}{|c|c|c|}
\hline Вид туризму & $\begin{array}{c}\text { Кількість } \\
\text { походів }\end{array}$ & $\begin{array}{l}\text { Кількість } \\
\text { учасників }\end{array}$ \\
\hline \multicolumn{3}{|c|}{2018 рік } \\
\hline Велотуризм & 2 & 10 \\
\hline Автомобільний & 2 & 17 \\
\hline Вітрильний & 5 & 48 \\
\hline Водний & 1 & 10 \\
\hline Всього & 12 & 61 \\
\hline \multicolumn{3}{|c|}{2019 рік } \\
\hline Лижний & 1 & 9 \\
\hline Велотуризм & 10 & 48 \\
\hline Автомобільний & 1 & 3 \\
\hline Вітрильний & 4 & 33 \\
\hline Мотоциклічний & 1 & 4 \\
\hline Пішохідний & 9 & 55 \\
\hline Водний & 3 & 24 \\
\hline Гірський & 2 & 17 \\
\hline Всього & 31 & 193 \\
\hline \multicolumn{3}{|c|}{2020 рік } \\
\hline Лижний & 1 & 9 \\
\hline Велотуризм & 1 & 6 \\
\hline Автомобільний & 3 & 17 \\
\hline Вітрильний & 4 & 24 \\
\hline Мотоциклічний & 3 & 5 \\
\hline Всього & 10 & 85 \\
\hline
\end{tabular}

технічна комісія) Федерації спортивного туризму України (ЦМКК ФСТУ) [6].

Чемпіонат України зі спортивного туризму туристські спортивні походи (дорослі, юніори, юнаки), III-IV ранг, протягом року з роз'їздами.

Треба зазначити, що Чемпіонати спортивних походів з різних видів туризму проводилися нерегулярно. Найбільша кількість походів до 2020 року припадає на 2019. До цього року їх чисельність збільшувалась. Але у зв'язку з карантином, який призвів COVID-19, кількість спортивних походів значно зменшилась. Позитивна динаміка була характерна для автотуризму, та мотоциклічного. А ось вело туризм, водний, пішохідний і гірський мають негативну динаміку.

За останні роки в Україні проведені різноманітні події зі спортивного туризму. Активно діє краєзнавство та дитячо-юнацький туризм. В країні діють близько 100 центрів туризму, станції юних туристів.

Найрозвиненіший регіон спортивно-оздоровчого туризму це Карпатський. Тут займаються більшою частиною спортивного туризму. Тут популярні: лижний, водний, пішохідний, велосипедний, а також $€$ можливість розвивати спелеотуризм [7].

Такі області як Луганська, Полтавська, Волинська, Львівська, Харківська, Дніпропетровська, Хмельницька, Черкаська мають велику кількість центрів туризму. Серед основних груп активного туризму в Україні популярні пішохідний, велосипедний та лижний туризм. Спортивні кружки приймають участь у Всеукраїнських змаганнях. Сьогодні більшість туристів в курортних областях намагаються вести активний спосіб відпочинку. Тому більшість регіональних туристських фрірм Західної України, Києва, Сум, Прикарпаття, Одеси, Харкова та інших міст розуміють, що спортивний туризм на сьогодні має комерційний потенціал, а не тільки соціальний [7].

Не дивлячись на великі можливості, на економічну та соціальну значущість спортивний туризм розвивається повільно, а можливо навіть недостатньо розвинутий.

Труднощі, 3 якими також зіткнувся спортивно-оздоровчий туризм у своєму розвитку, це економічні проблеми розвитку суспільства в першу чергу. На жаль, на сьогоднішній день майже повністю відсутня підтримка цього виду від держави та громади.

В останні роки дуже сильно зменшилася кількість походів вищого рівня. Ще однією 3 причин став воєнний конфрлікт між Росією та Україною. Багато районів, які були достат- 
ньо популярними, куди можна було дістатися відносно недорого, стали недоступними 3 2014 року. Нові можливі райони освоюються та розвиваються досить повільно.

Спортивний туризм цілком спокійно може розвиватися в умовах економічної кризи. Адже для нього не $є$ головним великі матеріальні витрати, він здатний існувати в навколишньому середовищі. Сьогодні можна побачити, як активний спосіб життя стає дуже популярним як серед молоді, так і серед старшого покоління. Тому зараз стрімко зростає кількість фрітнес-центрів.

Висновки 3 проведеного дослідження. Щоб в країні створити гарні умови для розвитку спортивного туризму треба залучити якомога більше людей, також об'єднати органи місцевого самоврядування, різні організації, спонсорів, державні органи законодавчої влади та інші.
Через те, що в Україні низький рівень розвиненості інфрраструктури, потрібно її покращувати в тих регіонах, де існують найкращі умови для спортивного туризму. Окрім цього, в тих регіонах, де цей вид туризму розвинений гірше, або зовсім відсутній, потрібно створювати інорраструктуру. Тобто, залучати дітей та студентів вести активний спосіб життя, організовувати різноманітні спортивні походи. Розробляти більше пішохідних та велосипедних маршрутів різної складності, а також облаштовувати гірські та гірськолижні маршрути для альпіністів і любителів лижного спорту. Треба створювати рекламу не тільки популярних для спортивного туризму регіонів, але й тих, які зараз недостатньо відомі. Також потрібно покращувати кваліфіковані кадри, підтримувати міжнародні стосунки та розвивати матеріально-технічну базу.

\section{СПИСОК ВИКОРИСТАНИХ ДЖЕРЕЛ:}

1. Мальська М.П., Худо В.В., Цибух В.І. Основи туристичного бізнесу. Київ : Центр навчальної літератури, 2004. 272 c.

2. Абрамов В.В. Спортивний туризм : підруч. для студ. спец. Туризм, Менеджмент організацій (Менеджмент готельного, курортного та туристичного сервісу). Харк. нац. акад. міськ. госп-ва. Харків : ХНАМГ, 2011. 367 с.

3. Joy Standeven and Paul de Knop. Sport tourism. Human Kinetics. 1999. P. 367.

4. James E.S. Higham. Sport tourism destinations: issues, opportunities and analysis. Butterworth-Heinemann. 2005. p. 300.

5. Heather J.Gibson. Sport tourism: concepts and theories. Taylor \& Francis Group. 2004. P. 224.

6. Офріційний сайт ЦМКК Федерації спортивного туризму України. URL: http://www.cmkk.com.ua//

7. Спортивний туризм в світі. URL: https://knowledge.allbest.ru/sport/2c0a65635b3ad78a4d53b884212 16d26_1.html

8. Поняття та види спортивного туризму. URL: https://tourlib.net/statti_ukr/shahova.htm

\section{REFERENCES:}

1. Malska M.P., Khudo V.V., Tsybukh V.I. (2004) Osnovy turystychnoho biznesu [Basics of tourist business]. Kyiv: Tsentr navchalnoi literatury, 272 p.

2. Abramov V.V. (2011) Sportyvnyi turyzm [Sports tourism]: pidruch. dlia stud. spets. Turyzm, Menedzhment orhanizatsii (Menedzhment hotelnoho, kurortnoho ta turystychnoho servisu). Khark. nats. akad. misk. hosp-va. Kharkiv: KhNAMH, 367 p.

3. Joy Standeven and Paul de Knop (1999) Sport tourism. Human Kinetics, p. 367.

4. James E.S. Higham (2005) Sport tourism destinations: issues, opportunities and analysis. ButterworthHeinemann, p. 300.

5. Heather J.Gibson (2004) Sport tourism: concepts and theories. Taylor \& Francis Group, p. 224.

6. Ofitsiinyi sait TsMKK Federatsii sportyvnoho turyzmu Ukrainy [Official site of the CMCK Federation of sports tourism of Ukraine]. Available at: http://www.cmkk.com.ua//

7. Sportyvnyi turyzm v sviti [Sports tourism in the world]. Available at: https://knowledge.allbest.ru/sport/ 2c0a65635b3ad78a4d53b88421216d26_1.html

8. Poniattia ta vydy sportyvnoho turyzmu [Concepts and types of sports tourism]. Available at: https://tourlib.net/ statti_ukr/shahova.htm 